\title{
A Descriptive Comparison Study between the Visitors Spent Time in Places in Saudi Arabia and New Zealand during COVID-19 Lock down and its Stimulus Package Economics Differences
}

\author{
Haitham Khoj ${ }^{1}$ and Alaa Mujallad ${ }^{2 *}$ \\ ${ }^{1}$ Department of Economics, King Abdulaziz University, Saudi Arabia \\ ${ }^{2}$ Department of Nursing, University of Jeddah, Saudi Arabia
}

*Corresponding author: Alaa Mujallad, Assistant Professor, Department of Nursing, College of Applied Medical Sciences, University of Jeddah, Saudi Arabia, Tel: 0555576511; Email: a_ mujallid@yahoo.com

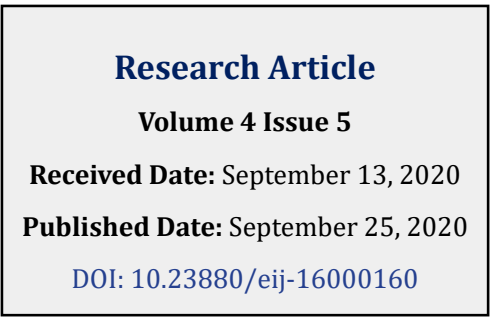

DOI: $10.23880 /$ eij-16000160

\section{Abstract}

Background: New Zealand has shown the world their successful results of their strict strategies to contain COVID-19. On March 25, New Zealand started the level 4 lock down. On June 8th, the prime minister announced that they had not had new cases in 17 days, and the COVID-19 patients had recovered. It was the only country at that time that has managed to have 0 cases of COVID-19 after a level 4 alert lock down. Although Saudi Arabia applied the same strategies as New Zealand, COVID-19 cases have increased. On March 29th, Saudi Arabia started level 4 lockdown when the COVID-19 cases were around 1453 , and then it reopened on May 28th, and the cases were around 80000.

Aims of the Study: In this study, we compare the percentage in the drop-down of the visitors spent time in places in Saudi Arabia and New Zealand compared to baseline days which is the median value of the five week period before the lockdown.

Methods: Secondary data was taken through google mobility that shows the visitors spent time in places in Saudi Arabia and New Zealand compared to baseline days which is the median value of the five week period before the lockdown 4 . A descriptive comparison was used to compare between the two countries.

Results: The results showed slight differences in daily activities among New Zealander and Saudi Arabian people.

Conclusion: Countries such as Saudi Arabia and New Zealand have done a stage 4 lockdown and have had different results. How did New Zealand manage at that time after the lockdown to have zero cases, and Saudi Arabia did not? It is a question that puzzles not only Saudi Arabia, but all other countries that could not lower the number of COVID-19 cases.

Keywords: COVID-19; Google Mobility

\section{Abbreviations: VAT: Value Added Tax.}

\section{Introduction}

The COVID-19 pandemic is one of the fastest transmitted diseases. It usually infects $2-3$ others, and the $\mathrm{R} 0$, which is the reproduction number, about 2.5. Many people assume that COVID-19 is like the Influenza pandemic, which is not true. There is a huge difference in the biology and the epidemiology of the SAR- CoV-2, which has a longer incubation period around five to six days than the one to three days incubation period of influenza. The long incubation period makes it difficult to contain COVID-19. By starting early to identify, isolate, trace, and quarantine [1]. For example, an effective strategy is needed to provide it. Many countries have begun to implement policies that could help them have positive outcomes by eliminating the number of cases until the virus disappears. 


\section{Epidemiology International Journal}

That will not happen without a good leader, acting fast for the sake of their citizens. Dr. Michael Baker is one of the key players who advised the New Zealand government to implement successful methods to contain COVID-19. According to Dr. Baker, "I think it was the right decision; we had to go hard." New Zealand started the lockdown on March 23 when the number of cases were less than 1500, and the deaths were only 20 [2].

New Zealand has shown the world their successful results of their strict strategies to contain COVID-19. On March 25, New Zealand started the level 4 lock down. On June 8th, the prime minister announced that they had not had new cases in 17 days, and the COVID-19 patients had recovered. It was the only country at that time that has managed to have 0 cases of COVID-19 after a level 4 alert lock down. Many countries have used the same strategies, but they did not contain COVID-19. New Zealand applied five strategies that helped them control the COVID-19 pandemic. The first strategy was to control the border and quarantine incoming travelers. The next strategy was widespread testing to discover the new cases very quickly and to start quarantining the contacted people. The third strategy was intensive hygiene promotion such as proper hand hygiene and cough etiquette. The fourth strategy was a strict lock-down level 4 alert that included closing of schools and workplaces as well as movement and travel restrictions. The last strategy is a good communication system strategy to educate the public about any updates regarding COVID-19 and what to do while they are sick [1]. Although Saudi Arabia applied the same strategies as New Zealand, COVID-19 cases have increased. On March 29th, Saudi Arabia started level 4 lockdown when the COVID-19 cases were around 1453, and then it reopened on May 28th, and the cases were around 80000 [3]. The positive thing at least in Saudi Arabia they flattened the curve and then they started to reopen. In this study, we want to compare the percentage in the drop-down of the visitors spent time in places in Saudi Arabia and New Zealand compared to baseline days which is the median value of the five week period before the lockdown.

\section{Methods}

Secondary data was taken through google mobility that shows the visitors spent time in places in Saudi Arabia and New Zealand compared to baseline days which is the median value of the five week period before the lockdown [4]. A descriptive comparison was used to compare between the two countries.

\section{Results}

Visitors to residential places were $29.5 \%$ in New
Zealand while in Saudi Arabia they were $26.6 \%$. Grocery and Pharmacy stores were $-39.8 \%$ in New Zealand, and $-35.2 \%$ in Saudi Arabia. Workplaces were -67.4 in New Zealand, and $64.2 \%$. Transit stations were also infected by the number of visitors as both countries ordered lockdowns; New Zealand dropped by-83.5, while Saudi Arabia by-68.8. Finally, retrial and recreation dropped significantly in both countries roughly by- $80 \%$ (Table 1 ).

\begin{tabular}{|c|c|c|}
\hline Category & New Zealand & Saudi Arabia \\
\hline Residential & 29.5 & 26.7 \\
\hline $\begin{array}{c}\text { Grocery and Pharmacy } \\
\text { Stores }\end{array}$ & -39.8 & -35.9 \\
\hline Parks & -68.8 & -53.2 \\
\hline Workplaces & -67.4 & -64.2 \\
\hline Transit Stations & -83.5 & -68.8 \\
\hline Retail and Recreation & -87.6 & -80.6 \\
\hline
\end{tabular}

Table 1: shows that New Zealand and Saudi Arabia are similar in the average number of visitors spent in categories places percentage change compared to base line days explained in the aim of the study.

This pie chart introduces the relative percentage change of each category in New Zealand; residential 8\%, grocery and pharmacy $-11 \%$, parks $-18 \%$, workplace $-18 \%$, retail and recreation $-23 \%$, and transit stations $-22 \%$ (Figure 1 ).

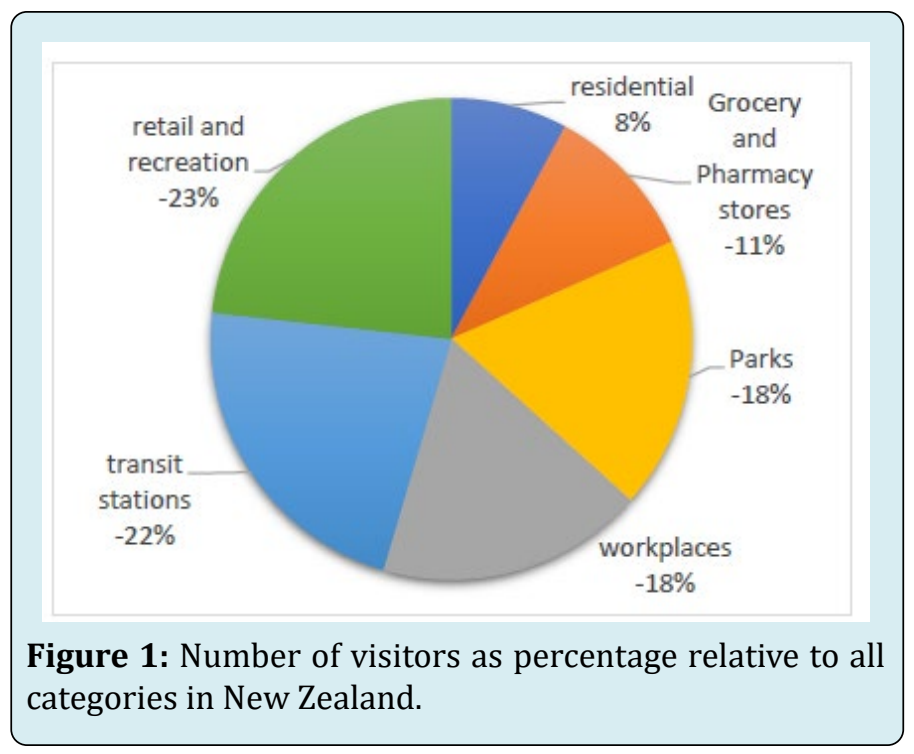

This pie chart introduces the relative percentage change of each category in Saudi Arabia; residential 8\%, grocery and pharmacy $-11 \%$, parks $-18 \%$, workplace $-16 \%$, retail and recreation - $26 \%$, and transit stations $-21 \%$ (Figure 2). 


\section{Epidemiology International Journal}

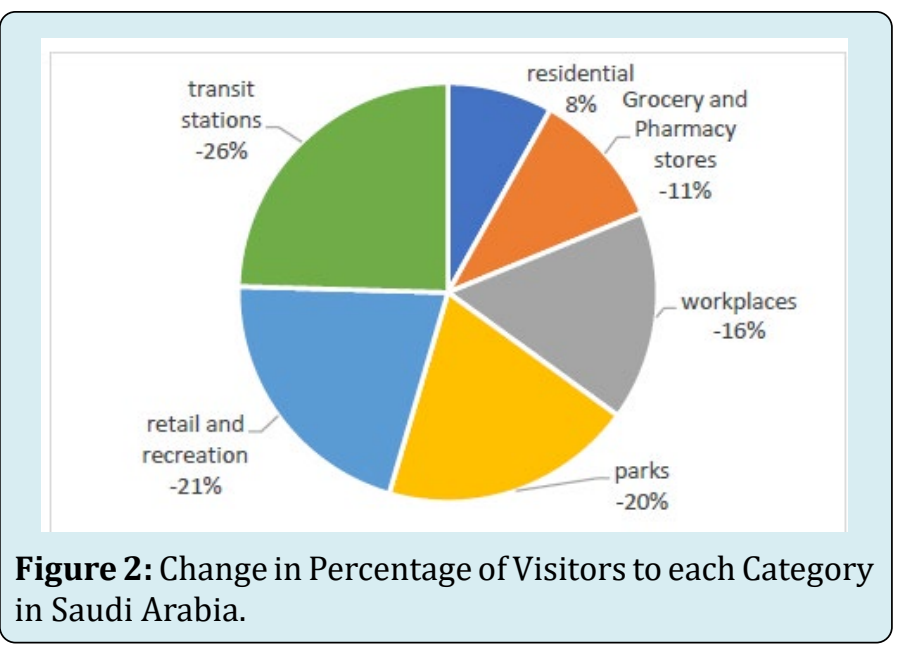

\section{Discussion}

The results showed slight differences in daily activities among New Zealander and Saudi Arabian people. However, how did New Zealand manage at that time after the lockdown to have zero cases, and Saudi Arabia did not? It is a question that puzzles not only Saudi Arabia, but all other countries that could not lower the number of COVID-19 cases. Saudi Arabia struggled to manage the virus during the lockdown; it could be due to many reasons.

The concept of senior homes is not popular and not widely accepted in the Saudi culture. Saudi Arabia is a family-centered community in which most of the families do not leave the elderly alone; most of the families are big and close emotionally and physically to each other. Many Saudi Arabians are considered cohesive; the extended members take care of the parents and grandparents. As a result, they all live together [5]. This will put family members at risk for infection because if one member contracts the virus, there will be a high chance for other members to also get infected.

The undocumented immigrants who have been living in Saudi Arabia for decades are one of the main reasons it is difficult to trace and track COVID-19 patients. Regardless, King Salman Al-Saud announced that all people who live in Saudi Arabia will receive free treatment for COVID-19, even those who reside there illegally. He added too that no one will face any legal consequences irrespective of immigration status because the main concern of the government of Saud Arabia right now is to contain the virus. Despite all of these efforts, it is still hard to contain the virus among them. Many of the undocumented immigrants live in condensed areas, especially in the city of Makkah. It is like a town in a big city. If one person contracts the virus, hundreds are at risk [6].

\section{The economic impact of COVID-19 on Saudi Arabia and New Zealand}

Saudi Arabia's economy is also negatively affected by COVID-19 in a different way than New Zealand's is. Each country copes differently to mitigate the economic impact of COVID-19. Saudi Arabia depends mainly on oil exporting and GDP per capita as of 2019 is 23139 USD [7], compared to New Zealand where GDP per capita is 42084 USD and their exports account for $30 \%$ of GDP [8].

\begin{tabular}{|c|c|c|}
\hline Category & Saudi Arabia & New Zealand \\
\hline Value Added Tax (VAT) & Increase from $5 \%$ to $15 \%$ as of July 1st, 2020. & No change \\
\hline Income Tax & No change & $\begin{array}{c}\text { Package worth of } \$ 2.8 \text { billion Give } \\
\text { more flexibility for businesses affected } \\
\text { businesses to meet their tax obligations }\end{array}$ \\
\hline Government expenditure & Cut of $\$ 30.23$ Billion & \\
\hline Banking & $\begin{array}{l}\text { Reduce the financial transactions cost Improve } \\
\text { electronic payments Reform outstanding credit } \\
\text { facilities with no interest or additional fees. } \\
\text { Support retail customer for those who lost their job } \\
\text { at private sectors. }\end{array}$ & $\begin{array}{c}\text { Free interest loan for all small businesses } \\
\text { up to } \$ 100,000 \text { to firms employing less } \\
\text { than } 50\end{array}$ \\
\hline Construction & Remained in progress & Remained in progress \\
\hline Consumer goods & Demand for durable goods declined & $\begin{array}{l}\text { Demand for durables goods declined } \\
\text { Stop increases in rent for six months }\end{array}$ \\
\hline E-commerce & Increased significantly & Increased significantly \\
\hline Wage subsidies & $\begin{array}{c}60 \% \text { of Saudi employees' salaries in the private } \\
\text { sector (up to } \$ 2400 \text { ) a total of } \$ 2.39 \text { Billion for } \\
\text { three months. }\end{array}$ & $\begin{array}{l}\$ 9-12 \text { billion to support private sectors to } \\
\text { pay their employees' salaries }\end{array}$ \\
\hline
\end{tabular}

Table 2: Stimulus Package differences between Saudi Arabia and New Zealand. 


\section{Epidemiology International Journal}

New Zealand is one of the OCED countries and has a diverse economy where it depends mainly on manufacturing and service sectors, as well as growing high-tech capabilities, tourism, and film production [9-11]. Each country implemented a different economic stimulus package to face COVID-19. Table 2 summarizes the most important actions to mitigate the impacts of COVID-19.

\section{Conclusion}

COVID-19 is a pandemic that people will tell stories about. Every human being is affected. The whole world has changed to reduce the spread of the disease. Until a vaccine or treatment is discovered, people will try the precautionary measures to reduce the spread of the disease. Countries such as Saudi Arabia and New Zealand have done a stage 4 lockdown and have had different results. The results showed slightly different decreased levels in daily activities among New Zealand and Saudi Arabian people.

\section{References}

1. Baker MG, Kvalsvig A, Verrall AJ, Barnard LT, Wilson N (2020) New Zealand's elimination strategy for the COVID-19 pandemic and what is required to make it work. N Z Med J 133(1512): 10-14.

2. Cousins S (2020) New Zealand eliminates COVID-19.
The Lancet 395(10235): 1474.

3. Ministry of Health https://covid19awareness.sa/en/ home-page

4. Google Mobility https://covid19awareness.sa/en/ home-page

5. Al Khraif R, Salam AA, Rashid MFA (2020) Family Demographic Transition in Saudi Arabia: Emerging Issues and Concerns. SAGE Open 10(1): 1-13.

6. Mujallad A, Khoj H (2020) Is there hope for the Hajj? Using the SIR Model to Forecast COVID-19 Progression in the City of Makkah.

7. (2019) World Bank. https://data.worldbank.org/ country/saudi-arabia

8. (2019) World Bank https://data.worldbank.org/ country/New Zealand

9. New Zealand trade and enterprise. https://data. Covid-19.nzte.govt.nz/page/Saudi- Arabia.

10. New Zealand trade and enterprise. https://data. Covid-19.nzte.govt.nz/page/New Zealand.

11. Argaam. https://www.argaam.com/en/article/ articledetail/id/135659. 